\title{
Kesesuaian Penerapan Manajemen Mutu Ikan Pindang Bandeng (Chanos chanos) Terhadap Standar Nasional Indonesia
}

\author{
Conformity Implementation of Quality Management Preserved Milkfish (Chanos chanos) \\ to the Indonesian National Standard
}

\author{
Elis Masrifah ${ }^{1 *}$, Bambang Pramudya Noorachmat ${ }^{2 *}$, Anggraini Sukmawati ${ }^{3 \#}$
}

${ }^{1}$ Dinas Peternakan dan Perikanan Kabupaten Bogor

Komplek Perkantoran PEMKAB Bogor. Jl. Bersih, Kel. Tengah, Kec. Cibinong

Telpon/Fax : 021-8765311

${ }^{2}$ Departemen Teknik Mesin dan Biosistem, Fakultas Teknologi Pertanian, IPB

${ }^{3}$ Departemen Manajemen Fakultas Ekonomi dan Manajemen, IPB

\#Jl. Kamper Kampus IPB Dramaga Bogor 16680

\begin{abstract}
ABSTRAK
Pengolahan hasil perikanan memegang peranan penting dalam kegiatan pasca panen, mengingat hasil perikanan merupakan komoditi yang sifatnya mudah rusak. Oleh karena itu diperlukan penanganan cepat dan tepat untuk menjaga mutunya. Memasuki era Asean Economic Community (AEC) pada tahun 2015 sektor industri perikanan tak kalah penting dari sektor lainnya, maka produk perikanan bermutu dan memiliki daya saing sangat diperlukan, agar mampu bertahan dan bersaing di pasar global. Salah satu unit pengolahan ikan di Kabupaten Bogor adalah UKM Cindy Group. UKM ini telah menerapkan cara pengolahan ikan secara modern dan mengikuti standar program kelayakan dasar pengolahan ikan. Tujuan penelitian ini adalah: (1) Menganalisis tingkat penerapan kelayakan dasar GMP (Good Manufacturing Practice) dan SSOP (Sanitation Standard Operating Procedures) pengolahan ikan pindang bandeng di UKM Cindy Group; (2) Menganalisis kesesuaian mutu setiap karakteristik ikan pindang bandeng yang diproduksi oleh Cindy Group terhadap persyaratan SNI Ikan Pindang No. 2717:2009. Metode penelitian bersifat deskriptif, dengan responden 30 orang menurut teknik penarikan contoh purposif. Hasil penilaian terhadap tingkat penerapan kelayakan dasar (GMP dan SSOP) menggunakan daftar penilaian Unit Pengolahan Ikan (UPI) yang diterbitkan oleh Ditjen P2HP tahun 2007 menunjukkan bahwa Cindy Group memperoleh SKP dengan rating "B", disebabkan adanya beberapa penyimpangan yang terjadi, yaitu 4 penyimpangan minor, 2 penyimpangan mayor, dan 1 penyimpangan serius. Secara Organoleptik dan kimia, pada umumnya mutu produk ikan pindang bandeng sudah memenuhi standar mutu menurut Standar Nasional Indonesia (SNI). Hasil uji organoleptik menggunakan uji hedonik menunjukkan nilai rataan di atas angka 7. Secara keseluruhan, tingkat penerapan program kelayakan dasar pada pengolahan ikan pindang bandeng Cindy Group sudah cukup baik. Persentase tingkat penerapan kelayakan dasar $92 \%$, sehingga secara umum produk ini layak untuk didaftarkan ke Badan Standarisasi Nasional (BSN) agar dapat mencantumkan label SNI pada kemasan produknya.
\end{abstract}

Kata Kunci: ikan pindang bandeng, manajemen mutu, pengolahan ikan, SNI




management systems such as Integrated Quality Management Program based on the concept of Hazard Analysis Critical Control Point (HACCP). One of fish processing units was existing in Bogor is Cindy Group (Small Medium Enterprises), they are producing preserved fishmilk. The purposes of the study are: (1) to analyze the level of implementation of the basic eligibility (GMP and SSOP) at Cindy Group, (2) to analyze the suitability of each characteristic quality of product against the requirements of SNI 2717: 2009. The study was conducted at Cindy Group SMEs located Bogor regency. The research method is descriptive with 30 respondents by purposive sampling. The results showed that based on the assessment of the level of implementation of the basic eligibility (GMP and SSOP) using UPI Assessment questionnaire published by Directorate General of the processing and marketing of fishery products, Ministry of Maritime Affairs and Fisheries) showed that SMEs Cindy Group obtained SKP the feasibility value "B" consisting of 4 minor irregularities, 2 major irregularities, and 1 serious irregularities. In quality, preserved milkfish products based on the results of testing Organoleptic and chemical have good quality according to SNI 2717: 2009. The results of organoleptic test using hedonic test showed an average value over than 7 (7 is minimum figure in SNI), indicates that the product can be accepted by consumers. Overall, the level of implementation of the basic eligibility processing program on processing of preserved milkfish in Cindy Group has been quite good, percentage rate of application of the basic feasibility is $92 \%$. This product can be registered to BSN to get the registration number of SNI and feasible to labeled SNI on product packaging.

Key words: preserved milkfish, process of fish, quality management, SNI

\section{PENDAHULUAN}

Ikan merupakan sumber utama protein hewani selain daging dan telur. Permintaan ikan untuk kebutuhan lokal maupun ekspor semakin meningkat dari tahun ke tahun. Disamping sebagai sumber pangan (gizi) utama, ikan merupakan komoditi yang menjadi obyek mata pencaharian bagi nelayan dan pelaku usaha pengolahan hasil perikanan. Program industrialisasi kelautan dan perikanan Kementerian Kelautan dan Perikanan yang berbasis pada minapolitan dengan menerapkan prinsip-prinsip blue economy, merupakan momentum baik untuk peningkatan daya saing produk perikanan di pasar domestik dan internasional. Program ini juga diharapkan akan menjadi upaya maksimal dalam rangka percepatan peningkatan kesejahteraan masyarakat khususnya nelayan, pembudidaya, pengolah, pemasar dan masyarakat lainnya.

Pengolahan hasil perikanan memegang peranan penting dalam kegiatan pascapanen, mengingat hasil perikanan merupakan komoditi yang sifatnya mudah rusak (perishable goods). Oleh karena itu diperlukan penanganan cepat dan tepat untuk menjaga mutunya hingga produk sampai ke tangan konsumen. Proses dan teknik pengolahan ikan yang sudah dikenal di masyarakat baik secara tradisional maupun modern yaitu pemindangan. Pada prinsipnya pemindangan dilakukan untuk menghentikan atau menghambat pertumbuhan mikroorganisme dan aktivitas enzim pada tubuh ikan yang dapat menyebabkan kerusakan.

Sakti (2012) menyatakan bahwa industri pengolahan hasil perikanan harus terus didorong dan dikembangkan agar bisa menghasilkan produk yang dicintai konsumen. Produk hasil pengolahan tersebut harus memiliki mutu baik, aman dikonsumsi, tersedia secara berkesinambungan, berdaya saing secara ekonomis dan sesuai dengan selera masyarakat. Kendala yang dihadapi pengolah ikan antara lain usaha pemindangan pada umumnya dilakukan dalam skala kecil, teknologi didapat secara turun menurun, sanitasi dan higiene kurang diperhatikan terutama oleh industri rumah tangga, sehingga mutu dan daya tahan ikan pindang menjadi kurang baik.

Menurut Taufiq (2008), UKM dituntut untuk menghasilkan produk yang memiliki daya saing yang tinggi dengan kriteria: (1) produk tersedia secara teratur dan sinambung, (2) produk harus memiliki mutu yang baik dan seragam, (3) produk dapat disediakan secara masal. Bagi UKM yang berusaha dalam bidang argibisnis (termasuk sektor perikanan) untuk memenuhi syarat ini tidaklah mudah, karena masih besarnya faktor alam dan terbatasnya teknologi produksi, processing, dan sumberdaya manusia.

Mutu adalah keseluruhan ciri atau karakteristik produk dalam tujuannya untuk memenuhi kebutuhan dan harapan konsumen. Jika konsumen merasa puas atas produk tersebut, maka perusahaan mendapatkan posisi terbaik di hati 
konsumen. Selain itu, mutu produk merupakan hal yang sangat penting dalam menciptakan strategi bersaing dengan perusahaan lain dan memberikan nilai tambah, memperpanjang masa simpan dan edar serta memperluas jangkauan pemasaran. Suatu produk dikatakan memiliki mutu yang baik apabila produk tersebut telah memiliki kesesuaian dengan standar yang telah ditetapkan. Salah satu standar yang ditetapkan oleh pemerintah adalah Standar Nasional Indonesia (SNI). SNI akan berperan dalam meningkatkan kemampuan industri dalam negeri untuk bersaing di pasar global. SNI juga akan menjadi penjaga dalam masuknya produk yang tidak bermutu ke pasar Indonesia. Untuk mencapai hal tersebut diperlukan pengendalian yang bertujuan untuk menganalisis penyimpangan yang terjadi terhadap standar yang ada. Hasil analisis tersebut digunakan untuk perbaikan sistem kerja, sehingga produk atau proses produksi sesuai dengan standar yang ditentukan.

Upaya yang harus dilakukan dalam rangka peningkatan mutu produk hasil perikanan adalah dengan mengendalikan proses pengolahan melalui penerapan sistem manajemen keamanan pangan berupa program kelayakan dasar berdasarkan konsep program manajemen mutu terpadu. Penerapan kelayakan dasar, yaitu cara berproduksi yang baik dan benar atau Good Manufacturing Practice (GMP) dan standar sanitasi atau Sanitation Standard Operating Procedures (SSOP). GMP dan SSOP perlu dilakukan pada semua jenis usaha perikanan baik modern maupun tradisional. Pada pengolahan pangan sistem manajemen mutu yang efektif dapat menjamin mutu dan keamanan produk. Penerapan sanitasi membahas pemeliharaan umum bangunan atau fasilitas usaha, bahan yang digunakan untuk pembersihan atau sanitasi, pengendalian hama, sanitasi permukaan, penyimpanan dan penanganan peralatan serta tempat pembuangan isi perut dan kotoran (Winarno dan Surono, 2004). Teknik penanganan dan pengolahan, teknik sanitasi dan higiene serta syarat mutu dan keamanan pangan ikan pindang disusun dalam suatu standar yaitu SNI 2717:2009.

Pengendalian dan pengawasan mutu yang baik tidak hanya dilakukan oleh produsen, namun diperlukan pihak lain yang dianggap memiliki kompetensi untuk mengawasi dan mengakreditasi produk yang dihasilkan oleh perusahaan. Salah satu lembaga akreditasi yang memiliki kewenangan dalam proses akreditasi suatu produk di Indonesia adalah Badan
Standarisasi Nasional (BSN) yang merupakan lembaga independen dan dianggap lebih obyektif serta memuaskan pihak produsen dan konsumen.

Salah satu unit pengolahan ikan di Kabupaten Bogor adalah Cindy Group, yaitu unit pengolahan ikan dengan teknik pemindangan. Berbagai macam jenis ikan diolah menjadi ikan pindang, salah satunya ikan bandeng (Chanos chanos). Pengolahan ikan bandeng dilakukan dengan cara tradisional dan modern. Cindy Group merupakan salah satu IKM pengolahan hasil perikanan yang menaruh perhatian pada mutu produknya dalam rangka menciptakan produk aman dikonsumsi dan memiliki tujuan jangka panjang menjadi produk unggulan Kabupaten Bogor yang dapat menembus pasar ekspor.

Tujuan penelitian ini adalah: (1) Menganalisis tingkat penerapan kelayakan dasar GMP dan SSOP pengolahan ikan pindang bandeng di UKM Cindy Group; (2) Menganalisis kesesuaian mutu setiap karakteristik ikan pindang bandeng yang diproduksi oleh Cindy Group terhadap persyaratan SNI 2717:2009.

\section{METODE PENELITIAN}

Metode penelitian yang digunakan adalah metode penelitian deskriptif. Proses pengambilan data dilakukan dengan cara survei, observasi dan wawancara dengan menggunakan panduan kuesioner. Penelitian dibagi menjadi dua tahap, yaitu (1) penilaian terhadap tingkat penerapan Program Kelayakan Dasar (GMP dan SSOP) di lokasi penelitian; (2) pengujian contoh produk ikan pindang bandeng sesuai persyaratan SNI 2717:2009 yaitu uji organoleptik, uji mikrobiologi dan uji kimia. Penilaian terhadap tingkat penerapan Program Kelayakan Dasar menggunakan kuesioner Sertifikat Kelayakan Pengolahan (SKP) Dirjen Pengolahan dan Pemasaran Hasil Perikanan Kementerian Kelautan dan Perikanan (P2HP KKP) tahun 2007, pengujian contoh dilakukan di laboratorium Institut Pertanian Bogor (IPB). Pengambilan contoh produk pindang ikan Bandeng mengacu pada SNI 2326:2010 tentang Metode Pengambilan contoh pada Produk Perikanan. Tipe penarikan contoh yang digunakan adalah penarikan contoh tunggal. Pada contoh tunggal, keputusan ditentukan berdasarkan hasil sampling lot.

Berdasarkan pada kondisi riil di lokasi penelitian, yaitu jumlah produksi ikan pindang bandeng sebanyak 200-350 kg per hari, maka 
jumlah pengambilan contoh yang refresentatif (mewakili) populasi lima ekor ikan. Contoh yang telah diambil segera diperiksa dan dianalisis untuk menghindari terjadinya kerusakan pada produk, mengingat produk tersebut merupakan barang mudah terkontaminasi oleh berbagai jenis mikroorganisme sehingga mudah rusak.

Uji organoleptik dilakukan dengan menggunakan kuesioner yang disebarkan kepada panelis. Penentuan panelis mengacu pada SNI 2346:2010 yaitu apabila panelis yang melakukan uji organoleptik merupakan panelis non ahli, maka jumlah panelis minimal yang melakukan uji organoleptik adalah 30 orang. Penentuan panelis menggunakan metode purposive sampling yaitu konsumen yang merupakan pelanggan produk tersebut. Uji organoleptik yang dilakukan pada penelitian ini adalah uji hedonik (hedonic test). Uji hedonik adalah metode uji yang digunakan untuk mengukur tingkat penerimaan (preference) konsumen terhadap suatu produk. Alat yang digunakan adalah kuesioner yang dikeluarkan oleh Dirjen P2HP KKP tahun 2007. Contoh yang digunakan yaitu produk ikan pindang bandeng yang diproduksi oleh Cindy Group pada tanggal 31 Oktober 2014.

\section{HASIL DAN PEMBAHASAN}

\section{Penilaian Tingkat Penerapan Kelayakan Dasar (GMP dan SSOP)}

Menurut Tjiptono dan Diana (1995) mutu secara umum mengandung unsur-unsur yang dapat diterima secara universal, yaitu: meliputi usaha memenuhi atau melebihi harapan pelanggan, mencakup produk, jasa manusia, proses, dan lingkungan, serta merupakan kondisi yang selalu berubah. mutu produk pangan yang baik harus menjamin keamanan produk tersebut untuk dikonsumsi oleh manusia, baik dilihat dari aspek mikrobiologi maupun aspek fisika-kimia dari produk tersebut.

Pengendalian mutu pangan menurut Hubeis (1999) erat kaitannya dengan sistem pengolahan yang melibatkan bahan baku, proses, pengolahan, penyimpangan yang terjadi dan hasil akhir. Program kelayakan dasar terdiri atas dua bagian pokok yaitu GMP dan SSOP (Wiryanti dan Witjaksono, 2001). GMP atau Cara Produksi Makanan yang Baik (CPMB) merupakan suatu pedoman cara memproduksi makanan dengan tujuan agar produsen memenuhi persyaratanpersyaratan yang telah ditentukan untuk meng- hasilkan produk makanan bermutu menurut konsumen (Thaheer, 2008). SSOP adalah prosedur pelaksanaan sanitasi standar yang harus dipenuhi oleh suatu UPI untuk mencegah terjadinya kontaminasi terhadap produk yang diolah. Sebagaimana diamanatkan dalam Undang-Undang (UU) No. 45 Tahun 2009 tentang Perubahan atas UU No. 31 Tahun 2004 tentang Perikanan pasal 20 ayat 3 bahwa setiap orang yang melakukan penanganan dan pengolahan ikan wajib memenuhi dan menerapkan persyaratan kelayakan pengolahan ikan, sistem jaminan mutu dan keamanan hasil perikanan, serta ayat 4 bahwa setiap orang yang memenuhi persyaratan kelayakan pengolahan ikan sebagaimana dimaksud pada ayat 3, memperoleh SKP, serta sesuai Peraturan Menteri KKP No. PER.19/MEN/2010 pasal 5 ayat 4 bahwa SKP diterbitkan oleh Direktur Jenderal P2HP sebagai hasil dari pembinaan terhadap UPI yang telah diterapkan Cara Pengolahan yang Baik (GMP) dan memenuhi persyaratan Prosedur Operasi Sanitasi Standar (SSOP).

Ruang lingkup GMP meliputi cara-cara berproduksi yang baik sejak bahan baku masuk ke pabrik sampai produk dihasilkan, termasuk persyaratan-persyaratan lainnya yang harus dipenuhi. Tahapan proses pembuatan ikan pindang bandeng di unit pengolahan ikan Cindy Group adalah: (1) penerimaan bahan baku; (2) Pencairan (thawing); (3) Penyiangan dan pencucian; (4) penyusunan ikan; (5) Pemasakan; (6) Pendinginan; (7) Pelumuran bumbu; (8) Pengemasan.

Menurut Susianawati (2006), mengacu pada peraturan Sea Food HACCP Regulation oleh FDA terdapat 8 kunci SSOP. Sesuai dengan hasil pengamatan di lokasi penelitian, penerapan SSOP tersebut adalah:

\section{Keamanan Air}

Air yang akan digunakan di pompa dan dialirkan melalui pipa/slang kemudian air ditampung dalam penampungan air. Sehingga air yang digunakan untuk proses pengolahan ikan adalah air yang telah diendapkan dalam wadah penampungan yang diberi kaporit atau tawas secukupnya. Pengujian terhadap mutu air yang digunakan telah dilakukan pada tanggal 14 Juli 2014. Parameter yang diuji diantaranya ALT (suhu $22^{\circ} \mathrm{C}$ dan $37^{\circ} \mathrm{C}$ ) dengan pedoman metode analisis ISO 6222:1999, Coliform dan E. Coli dengan berpedoman pada SNI ISO 9308:1:2010 dan Enterococci berpedoman pada SNI ISO 7899:2: 2010. Hasil pengamatan terhadap semua contoh menunjukkan hasil negatif. 
2. Kondisi kebersihan permukaan yang kontak dengan bahan pangan

Peralatan, wadah yang digunakan kondisinya cukup bersih. Seperti keranjang dari plastik, keranjang anyaman bambu, ember dan parapara. Sebelum kegiatan mulai dan selesai kegiatan, peralatan dibersihkan dengan cara disikat dan disabun kemudian dikeringkan. Hal ini diharapkan dapat mengurangi terjadinya kontaminasi terhadap produk. Penempatan peralatan diletakkan diruang yang terpisah dengan ruang pengolahan dan pengemasan.

\section{Pencegahan Kontaminasi Silang}

Gudang bahan baku memiliki bangunan tersendiri dan terpisah dengan lokasi pengolahan. Kebersihan dan sanitasi area pengolahan terjaga dengan baik. Begitu pula dengan praktek hygiene pekerja, pakaian dan pencucian tangan berada dalam kondisi yang baik.

4. Fasilitas pencucian tangan, sanitasi dan toilet Kondisi fasilitas cuci tangan, toilet terjaga dengan baik. demikian juga dengan konsentrasi bahan sanitasi tangan tersedia menurut yang disyaratkan. Jumlah bak cuci tangan di dalam ruangan proses produksi sebanyak dua buah. Jumlah ini telah mencukupi jika dibandingkan dengan jumlah karyawan yang bekerja di ruang proses produksi \pm 12 orang.

5. Proteksi dari bahan-bahan kontaminan

Proteksi belum dilakukan dengan sempurna, terlihat dengan tidak adanya jadwal monitoring secara berkala sesaat sebelum melakukan produksi dan setiap enam jam yang dilakukan terhadap bahan-bahan yang berpotensi menjadi kontaminan seperti pemeriksaan aliran udara, sehingga ruangan produksi tidak mengalami kondensasi, pemeriksaan air pencucian kaki sebelum masuk ruang produksi dan secara kontinu melakukan pembuangan bahan kimia tanpa label.

6. Pelabelan, penyimpanan dan penggunaan bahan toksin yang benar

Pelabelan, penyimpanan dan penggunaan terhadap bahan toksin dilakukan kurang sempurna. Tidak Terlihat jadwal waktu monitoring secara berkala yang harus dilakukan setiap hari oleh karyawan.

7. Pengawasan kondisi kesehatan personil yang dapat mengakibatkan kontaminasi

Karyawan yang bekerja di ruang pengolahan, penyortiran, pengemasan harus selalu menggunakan sarung tangan. Hal ini dilakukan untuk menjaga kebersihan dengan memper- hatikan aspek sanitasi dan hygiene, karena sarung tangan merupakan sumber potensial dari kontaminan, maka harus dibersihkan dan disanitasi. Karyawan selalu menggunakan sepatu boot sebagai alas kaki.

8. Menghilangkan hama dari unit pengolahan Tujuan dari kunci ke delapan ini adalah untuk menjamin tidak adanya hama dalam bangunan pengolahan pangan. Beberapa hama yang mungkin membawa penyakit adalah:

a. Lalat dan kecoa: mentransfer Salmonella, Streptococcus, C. Botulinum, Staphylococcus, C. perfringens, Shigella.

b. Binatang pengerat: sumber Salmonella dan parasit

c. Burung: pembawa variasi bakteri Salmonella dan Listeria.

\section{Tingkat Penerapan Program Kelayakan Dasar}

Berdasarkan penilaian di lokasi penelitian, tingkat penerapan Program Kelayakan Dasar (GMP dan SSOP) menggunakan daftar penilaian UPI yang diterbitkan oleh Ditjen P2HP tahun 2007 menunjukkan bahwa Cindy Group memperoleh rating " $\mathrm{B}$ " karena terdapat beberapa penyimpangan yang terjadi di lokasi pengolahan. Penyimpangan-penyimpangan tersebut terdiri atas 4 penyimpangan minor, 2 penyimpangan mayor dan 1 penyimpangan serius. Penyimpangan minor adalah penyimpangan yang apabila tidak dilakukan tindakan koreksi atau dibiarkan secara terus menerus akan berpotensi memengaruhi mutu pangan. Penyimpangan mayor adalah penyimpangan yang apabila tidak dilakukan tindakan koreksi mempunyai potensi dapat memengaruhi keamanan pangan, sedangkan penyimpangan serius adalah penyimpangan yang apabila tidak dilakukan tindakan koreksi dapat memengaruhi keamanan pangan (DJP2HP, 2007). Penyimpangan-penyimpangan tersebut dapat dilihat pada Tabel 1.

\section{Pengujian Contoh Produk Ikan Pindang Bandeng}

Pengujian contoh merupakan bagian dari tahapan analisis mutu pada penelitian ini. Pengujian mutu produk terdiri dari uji organoleptik, uji mikrobiologi (Angka Lempeng Total (ALT), Escherichia coli, salmonella, vibrio cholerae dan Staphyloccocus aureus), dan uji kimia (kadar air dan garam), dengan hasil berikut: 
Tabel 1. Penyimpangan (deficiency) yang terjadi di Cindy Group

\begin{tabular}{|c|c|c|c|}
\hline $\mathrm{No}$ & Penyimpangan Minor & Penyimpangan Mayor & Penyimpangan Serius \\
\hline 1 & $\begin{array}{l}\text { Tidak ada peringatan pada tempat } \\
\text { penyimpanan bahan kimia }\end{array}$ & $\begin{array}{l}\text { Lubang angin tidak dilengkapi } \\
\text { dengan bahan/alat yang dapat } \\
\text { mencegah masuknya serangga }\end{array}$ & $\begin{array}{l}\text { Tidak terdapat } \\
\text { tempat penyimpanan } \\
\text { bahan kimia } \\
\text { tersendiri }\end{array}$ \\
\hline 2 & $\begin{array}{l}\text { Tidak terdapat pemantauan pembuangan } \\
\text { wadah dan peralatan yang rusak }\end{array}$ & $\begin{array}{l}\text { Ruang pengolahan } \\
\text { berhubungan langsung dengan } \\
\text { tempat tinggal pemilik }\end{array}$ & - \\
\hline 3 & Tidak terdapat ruang istirahat & - & - \\
\hline 4 & Pencegahan serangga dan tikus tidak efektif & - & - \\
\hline
\end{tabular}

\section{a. Hasil Uji Organoleptik}

Dari hasil penilaian uji hedonik diperoleh angka rataan (mean) contoh sebesar 7,25 dengan nilai standar deviasi (mean SD) 0,665 dan standar error mean (mean $\pm S E M$ ) 0,121. Dari perbandingan angka mean (SEM) terhadap mean diperoleh nilai sangat kecil, hal ini menunjukkan contoh yang dianalisis dapat merepresentasikan keseluruhan populasi (lot) dari produk ikan pindang bandeng yang diproduksi pada saat pengambilan contoh.



Gambar 1. Grafik nilai uji organoleptik

Berdasarkan Gambar 1 dapat dilihat bahwa hasil uji hedonik terhadap parameter kelunakan memiliki nilai rataan paling tinggi 7,40 , diikuti oleh parameter rasa 7,31, aroma 7,25, tekstur 7,19, dan warna 7,09. Hal ini menunjukan konsumen sebagai panelis sangat menyukai kelunakan dari produk ini. Dari data hasil penilaian tersebut dilakukan uji statistik untuk menguji perbedaan mean dengan metode One-way ANOVA (Analisis of Variance). Analisis menunjukkan angka sig = 0,434 dan nilai F Hitung 0,956. Angka ini menunjukkan bahwa tidak ada perbedaan yang nyata antar parameter organoleptik, sehingga disimpulkan data setiap parameter uji organoleptik memiliki ragam yang sama.

\section{b. Hasil Uji Mikrobiologi}

Uji mikrobiologi merupakan uji salah satu uji yang penting, karena selain dapat menduga daya tahan simpan makanan, juga dapat dijadikan sebagai indikator sanitasi makanan atau indikator keamanan makanan. Pengujian mikrobiologi meliputi uji kuantitatif untuk menentukan mutu dan daya tahan suatu makanan, uji kualitatif bakteri patogen untuk menentukan tingkat keamanannya dan uji bakteri indikator untuk mengetahui tingkat sanitasi makanan tersebut (Fardiaz, 1993). Pengujian mikrobiologi pada contoh makanan akan selalu mengacu kepada persyaratan makanan yang sudah ditetapkan. Parameter uji mikrobiologi pada ikan pindang bandeng yang dipersyaratkan sesuai SNI meliputi ALT, Escherichia coli, Salmonela, Vibrio cholerae dan Staphyloccocus aureus. Hasil pengujian terhadap lima contoh ikan pindang bandeng dimuat pada Tabel 2.

\section{1) Hasil Uji ALT}

Metode yang digunakan untuk mengetahui jumlah mikroba dalam produk ikan pindang bandeng adalah metode kuantitatif. Menurut BPOM RI (2008) Metode kuantitatif digunakan untuk mengetahui jumlah mikroba yang ada pada sampel ikan pindang bandeng. Penilaian hasil uji ALT produk ikan pindang bandeng berada dibawah ambang batas jumlah standar SNI (5,0 x $10^{5}$ koloni g-1 $^{-1}$. secara keseluruhan ratarata hasil uji ALT adalah sebesar 5,4 x 102 koloni $\mathrm{g}^{-1}$, Sehingga dikatakan bahwa jumlah nilai ALT pada sampel ikan pindang bandeng dari Cindy Group masih berada dibawah ambang batas jumlah standar yang dipersyaratkan 2717:2009 (Gambar 2). Nilai pengujian ALT ini digunakan untuk mengukur derajat pencemaran, sehingga dilihat dari hasil perhitungan ALT contoh produk dapat dikatakan bahwa contoh produk baik dan aman dikonsumsi oleh manusia. 
Tabel 2. Hasil uji mikrobiologi contoh ikan pindang bandeng

\begin{tabular}{lccc}
\hline \multicolumn{1}{c}{ Jenis Uji } & Satuan & Standar SNI & Hasil Uji Contoh \\
\hline a. Organoleptik & & & \\
- Nilai & Angka (1-9) & Min 7 & Negatif \\
- Kapang & & & NA \\
b. Cemaran Mikroba & Koloni g-1 & Maks $5,0 \times 10^{5}$ & $5,4 \times 10^{2}$ \\
- ALT & APM g-1 & Maks $<3$ & Negatif \\
- Escherichia coli & APM 25 g-1 & Negatif & Negatif \\
- Salmonella & APM 25 g-1 & Negatif & Negatif \\
- Vibrio cholerae & Koloni g-1 & $1 \times 10^{3}$ & $1 \times 10^{2}$ \\
- Staphyloccocus aureus & & & \\
c. Kimia & $\%$ fraksi massa & Maks 60 & $54-57$ \\
- Air & $\%$ fraksi massa & Maks 10 & $1,21-1,67$ \\
- Garam & Mg/kg & Maks 100 & NA \\
- Histamin & &
\end{tabular}

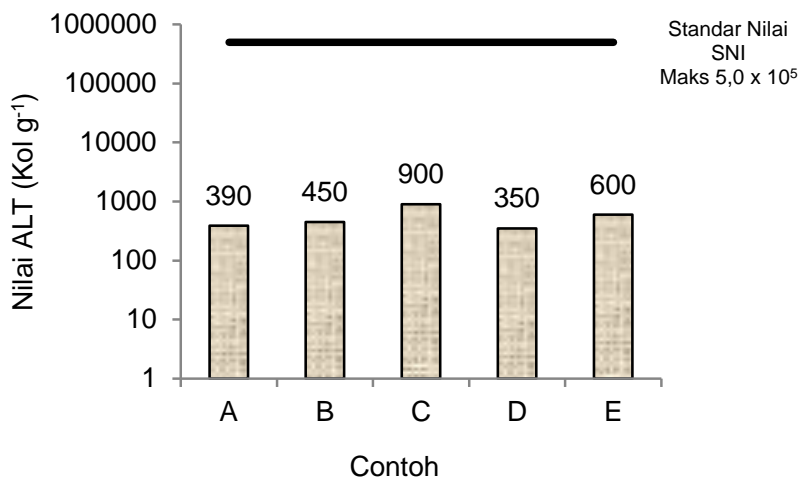

Gambar 2. Grafik nilai uji ALT

\section{2) Hasil Uji Escherichia coli}

Bakteri yang paling banyak digunakan sebagai indikator sanitasi adalah Escherichia coli karena bakteri ini adalah bakteri komensal pada usus manusia dan umumnya bukan patogen penyebab penyakit. Berdasarkan pengujian terhadap lima contoh produk ikan pindang bandeng yang di produksi oleh Cindy Group dengan mengacu pada metode standar yaitu SNI 012332.1.2006 dinyatakan bahwa contoh tidak teridentifikasi bakteri E. coli. Media yang digunakan pada pengujian produk ini adalah Eosin Methylene Blue Agar (EMBA) yang dapat menumbuhkan bakteri kelompok Enterobacteriaceae, salah satunya adalah E. coli yang akan tumbuh dengan membentuk koloni berwarna hijau dengan kilap logam. EMBA adalah media selektif dan media differensial. Media diferensial merupakan media yang dapat menumbuhkan beberapa jenis bakteri dan menyebabkan koloni-koloni suatu bakteri tertentu mendapatkan bentuk yang khas. EMBA juga mengandung karbohidrat laktosa, sehingga media ini cocok untuk menguji produk yang mensyaratkan hasil uji dengan kandungan $E$. coli negatif.

\section{3) Hasil Uji Salmonella}

Salmonella adalah salah satu bakteri yang seringkali menyebabkan penyakit yang cukup serius apabila mencemari makanan yang dikonsumsi manusia. Pada pengujian identifikasi bakteri Salmonella, metode yang digunakan adalah metode analisa secara kualitatif (positif/negatif). Metode analisa kualitatif ini memiliki tahapantahapan tertentu dengan tujuan mengetahui ada tidaknya suatu mikroorganisme dalam makanan. Dari pengidentifikasian bakteri Salmonella pada metode ini adalah untuk mengetahui mutu suatu produk berdasarkan kemasan atau sifat mikrobiologinya. Keseluruhan contoh yang diuji menunjukkan negatif Salmonella.

\section{4) Hasil Uji Vibrio cholerae}

Vibrio cholerae merupakan bakteri gram negatif, berbentuk basil (batang) dan bersifat motil (dapat bergerak). Spesies $V$. cholerae kerap dikaitkan dengan sifat patogenesisnya pada manusia, terutama $V$. cholerae penyebab penya-kit kolera. Metode yang digunakan untuk pengujian contoh mengacu pada SNI 01.2332.4 tahun 2006. Pengujian dilakukan secara kualitatif dengan metode pengkayaan (enrichment) yaitu contoh yang diuji ditumbuhkan terlebih dahulu pada media pengkayaan dan dideteksi dengan menumbuhkan pada media agar selektif. Kolonikoloni yang diduga $V$. Cholerae pada media agar selektif diisolasi kemudian dilanjutkan dengan konfirmasi melalui uji biokimia dan uji serologi untuk meyakinkan ada atau tidaknya $V$. Cholerae. Hasil pengujian terhadap lima contoh produk ikan pindang bandeng yang di produksi oleh Cindy Group dinyatakan negatif. 


\section{5) Hasil Uji Staphyloccocus aureus}

Staphyloccocus aureus merupakan bakteri coccus gram positif, susunannya bergerombol dan tidak teratur seperti anggur. S. aureus tumbuh pada media cair dan padat seperti NA (Nutrien Agar) dan BAP (Blood Agar Plate) dan aktif melakukan metabolisme, mampu fermentasi karbohidrat dan menghasilkan bermacam-macam pigmen dari putih hingga kuning. Gejala keracunan makanan yang terkena bakteri S. aureus sifatnya ringan dan akan sembuh dengan sendirinya meskipun tanpa pengobatan. Metode yang digunakan untuk pengujian contoh mengacu pada SNI 2332.9 tahun 2011.

Pengujian dilakukan dengan menggunakan metode cawan hitung (plate count) agar sebar. Metode cawan hitung agar sebar adalah dengan cara menuangkan media Baird Parker Agar ke dalam cawan petri steril, biarkan membeku, kemudian contoh sebanyak $1 \mathrm{ml}$ disebar di atas permukaan media. Konfirmasi koloni terduga $S$. aureus dilakukan dengan uji koagulase dan uji tambahan. Metode ini sesuai untuk menganalisis makanan yang diduga mengandung koloni lebih dari 100 Staphylococcus aureus per gram.

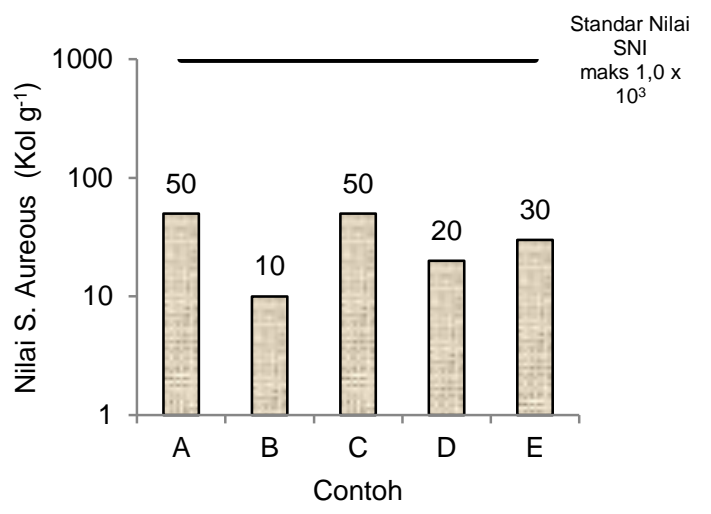

Gambar 3. Grafik nilai uji S. aureus

\section{c. Hasil Uji Kimia \\ 1) Uji Kadar Air}

Kadar air merupakan banyaknya air yang terkandung dalam bahan yang dinyatakan dalam persen. KA merupakan salah satu karakteristik yang sangat penting pada bahan pangan, karena air dapat memengaruhi penampakan, tekstur dan citarasa pada bahan pangan tersebut. KA dalam bahan pangan ikut menentukan kesegaran dan daya awet bahan pangan tersebut, KA yang tinggi mengakibatkan mudahnya bakteri, kapang dan khamir untuk berkembang biak, sehingga akan terjadi perubahan pada bahan pangan (Afrianto dan Liviawaty, 1989).

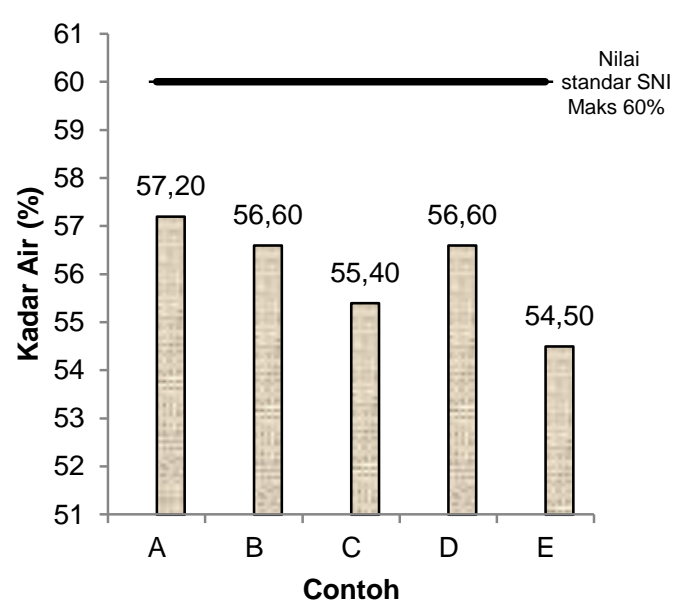

Gambar 4. Grafik nilai hasil uji KA

Menurut SNI 2717:2009 batas maksimum kadar air pada ikan pindang bandeng adalah $60 \%$. Dari kelima contoh yang diuji, secara umum kandungan KA dalam contoh produk telah memenuhi persyaratan SNI yaitu berkisar $54-57 \%$ (Gambar 4). Penyusutan air terjadi karena adanya penguapan pada saat proses perebusan, sehingga ikan mengeluarkan air dari jaringan otot daging. Menurut Hadiwiyoto (1993) dengan pemanasan, protein ikan akan mengalami denaturasi seluruhnya yang disertai dengan terjadinya pengeluaran air dari jaringan otot daging ikan. Denaturasi adalah sebuah proses dimana protein atau asam nukleat kehilangan struktur tersier dan struktur sekunder dengan penerapan beberapa tekanan eksternal atau senyawa, seperti asam kuat atau basa, garam anorganik terkonsentrasi. Gaman dan Sherrington (1994) menyatakan bahwa denaturasi bisa disebabkan pemanasan, sehingga air yang terdapat dalam bahan pangan menguap.

Dari data hasil penilaian kemudian dilakukan uji statistik untuk menguji perbedaan mean dengan menggunakan metode Analisis of Variance (ANOVA). Hasil analisis menunjukkan sig $=0,343$ dan nilai $\mathrm{F}$ Hitung $=1,197$. Angka ini menunjukkan bahwa tidak ada perbedaan nyata antar contoh, sehingga dapat disimpulkan bahwa data setiap contoh memiliki ragam sama.

\section{2) Uji Kadar Garam}

Menurut Sudarmadji et al. (1989), penentuan KG dapat dilakukan metode Kohman, yaitu dengan prinsip mengekstraksi contoh sehingga garam (NaCL) dipisah dengan lemak dan kemudian dititrasi. Contoh ikan pindang bandeng yang telah dihaluskan ditimbang sebanyak $5 \mathrm{~g}$, kemudian diekstrak menggunakan aquades panas 
10-20 ml, ditunggu beberapa lama agar semua garam $(\mathrm{NaCl})$ larut dan terpisah dengan lemak. Ekstraksi diulang sebanyak 5 kali. Cairan hasil ekstraksi ditampung dalam wadah kemudian ditambah $3 \mathrm{ml}$ kalium khromat 5\% dan dititrasi dengan perak nitrat $\left(\mathrm{AgNO}_{3}\right) \quad 0,1 \mathrm{~N}$ secara perlahan-lahan sampai warna menjadi merah bata. Hasil analisa KG dari kelima contoh ikan pindang bandeng yang diuji dapat dilihat pada Gambar 5.

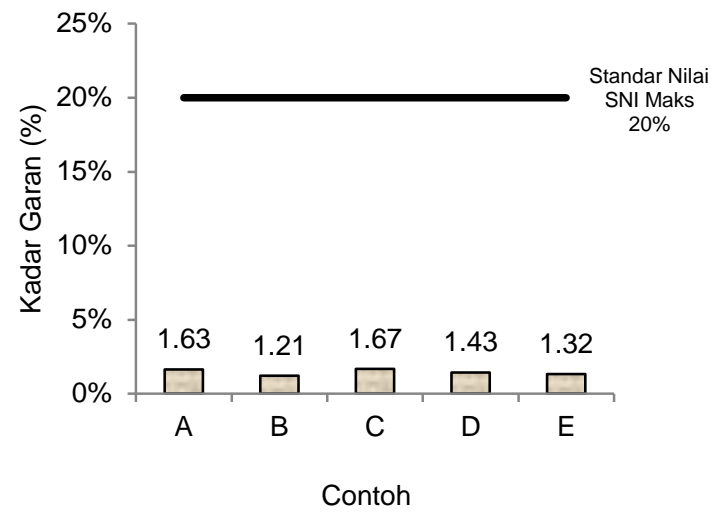

Gambar 5. Grafik nilai hasil uji kadar garam

KG yang terkandung dalam contoh sangat rendah berkisar 1,21-1,67\%. Nilai tersebut menunjukkan bahwa KG yang terkandung dalam contoh sudah memenuhi persyaratan SNI yaitu tidak lebih dari 10\%. Hasil analisis statistik menggunakan ANOVA diperoleh nilai F hitung 13,772 lebih besar dari F Tabel 2,87 dan diperkuat dengan nilai $\mathrm{p}=0,000(\mathrm{P}<0,05)$, sehingga dapat disimpulkan terdapat perbedaan kadar garam antar contoh. Karena hasil uji ANOVA menunjukkan adanya perbedaan antar contoh, kemudian dilakukan uji perbandingan ganda (multiple comparisons) untuk melihat kelompok contoh mana saja yang memiliki perbedaan KG. Dari Hasil analisis menggunakan metode Tukey terlihat bahwa perbedaan yang nyata terjadi antara contoh $\mathrm{A}$ dengan $C$ sebesar $p=0,000$, contoh A dengan $E$ sebesar $p=0,000$, contoh $B$ dengan $C$ sebesar $p=0,002$, contoh $B$ dengan $E$ sebesar $p=0,002$, contoh $C$ dengan $D$ sebesar $p=0,026$ dan contoh $D$ dengan E sebesar $\mathrm{p}=0,026$.

\section{Implikasi Manajerial}

Penelitian ini telah menunjukkan bahwa pelaksanaan GMP dan SSOP dalam proses pengolahan ikan pindang sangat penting untuk menghasilkan produk ikan pindang yang bermutu baik, terjamin keamanannya dan sesuai dengan harapan konsumen. Dengan demikian tahapan-tahapan perbaikan terhadap beberapa penyimpangan yang terjadi menjadi hal utama dalam proses perbaikan di masa mendatang. Hasil penelitian ini memberikan beberapa implikasi, yaitu:

1. Implikasi perbaikan terhadap penyimpang-an minor berikut:

a. Membuat tanda peringatan pada tempat penyimpanan bahan kimia.

b. Membuat lembar kontrol untuk melakukan pemantauan pada wadah dan peralatan yang sudah rusak atau tidak digunakan lagi.

c. Membuat ruang istirahat untuk karya-wan.

d. Menyediakan alat pengendali hama berupa insect killer yang dapat menarik perhatian serangga seperti lalat dan kecoa.

2. Implikasi perbaikan terhadap penyimpang-an mayor berikut:

a. Memperbaiki lubang angin di ruang pemasakan, melengkapinya dengan memasang kasa pencegah masuknya serangga

b. Memperbaiki tata letak dan alur proses produksi UPI dengan cara memisahkan ruang pengolahan dengan tempat tinggal pemilik.

3. Implikasi perbaikan terhadap penyimpang-an serius adalah membuat tempat penyimpanan (gudang) bahan kimia dan terpisah dari ruang pengolahan.

\section{KESIMPULAN}

Penelitian tentang kesesuaian penerap-an manajemen mutu produk ikan pindang bandeng di Cindy Group adalah:

1. Tahapan proses pemindangan ikan bandeng di Cindy Group adalah penerimaan bahan baku, pencairan, penyiangan dan pencucian, penyusunan ikan, pemasakan, pelumuran bumbu, pendinginan dan pengemasan. Secara keseluruhan, prosedur penerapan program kelayakan dasar (GMP dan SSOP) yang dilaksanakan oleh Cindy Group sudah cukup baik dan sesuai program kelayakan dasar yang dirumuskan oleh Direktorat Jenderal Pengolahan dan Pemasaran Hasil Perikanan, Kementerian Kelautan dan Perikanan, tetapi dalam pelaksanaannya terjadi penyimpangan memberikan penilaian kurang baik terhadap proses produksi pindang ikan bandeng.

2. Penyimpangan yang terjadi di Cindy Group terdiri atas 4 penyimpangan minor, 2 penyimpangan mayor dan 1 penyimpangan serius. 
Penyimpangan ini menyebabkan Cindy Group memperoleh nilai kelayakan "B", sehingga tidak sesuai dengan SKP yang dikeluarkan oleh Direktorat Jenderal P2HP KKP tahun 2013 dengan nilai kelayakan " $\mathrm{A}$ ", maka perlu dilakukan tindakan koreksi untuk memperbaiki penyimpangan-penyimpangan tersebut.

3. Secara Organoleptik dan kimia, pada umumnya mutu produk ikan pindang bandeng sudah memenuhi standar mutu menurut SNI. Hasil uji organoleptik menggunakan metode uji hedonik menunjukkan nilai rataan di atas angka 7. Hal ini menunjukan bahwa mutu produk ikan pindang bandeng produksi Cindy Group dikaji dari karakteristik sensori maupun penerimaan konsumen telah memenuhi standar SNI. Secara keseluruhan, tingkat penerapan program kelayakan dasar pada pengolahan ikan pindang bandeng di Cindy Group sudah baik.

\section{DAFTAR PUSTAKA}

Afrianto E, Liviawaty E. 1989. Pengawetan dan Pengolahan Ikan. Kanisius, Yogyakarta (ID).

[BPOM] Badan Pengawas Obat dan Makanan. 2008. Pengujian Mikrobiologi Pangan. Jurnal Infopom. Vol. 9. No 2. 2009.

[BSN] Badan Standarisasi Nasional. 2009. SNI 2717.1:2009 tentang Ikan Pindang- Bagian 1: Spesifikasi. BSN, Jakarta (ID).

[BSN] Badan Standarisasi Nasional. 2009. SNI 2717.2:2009 tentang Ikan Pindang- Bagian: Persyaratan Bahan Baku. BSN, Jakarta (ID).

[BSN] Badan Standarisasi Nasional. 2009. SNI 2717.3:2009 tentang Ikan Pindang- Bagian 3: Penanganan dan Pengolahan. BSN, Jakarta (ID).

Fardiaz S. 1993. Analisis Mikrobiologi Pangan. Raja Grafindo Persada, Jakarta (ID).

Gaman PM, Sherrington KB. 1994. Pengantar Ilmu Pangan, Nutrisi dan Mikrobiologi. Ed ke-4.
Gardjito M, penerjemah; Kasmidjo RB, penyunting. Yogyakarta (ID). UGM Pr. Terjemahan dari: The Science of Food: Introduction to Food Science, Nutrition and Mikrobiology. Ed ke-4.

Hadiwiyoto S. 1993. Teknologi Pengolahan Hasil Perikanan. Jilid I. Liberty, Yogyakarta (ID).

Hubeis M. 1999. Sistem Jaminan Mutu Pangan. Di dalam Pelatihan Pengendalian Mutu dan Keamanan Bagi Staf Pengajar. Kerjasama Pusat Studi Pangan dan Gizi IPB dengan Direktorat Jenderal Pendidikan Tinggi, Departemen Pendidik-an dan Kebudayaan. Bogor (ID).

Sakti, I. 2012. KKP Genjot Diversifikasi Produk Olahan Ikan. Siaran Pers No B.54/PDSI/ HM.310/IV/2012 [Internet] [diacu 2014 April]. Tersedia dari: http://www.kkp.go.id/ index.php/arsip/c/7645/kkp-genjotdiversifikasi-produk-lahan ikan.

Sudarmadji S, Haryono B, Suhardi. 1989. Analisis Bahan Makanan dan Pertanian. Liberty, Yogyakarta (ID).

Susianawati R. 2006. Kajian Penerapan GMP dan SSOP pada Produk Ikan Asin dalam Upaya Peningkatan Kemanan Pangan di Kabupaten Kendal. Tesis. Universitas Diponegoro. Semarang (ID).

Taufiq M. 2008. Strategi Pengembangan UKM pada Era Otonomi Daerah dan Perdagangan Bebas. Departemen Koperasi dan UKM, RI. Jakarta (ID).

Thaheer H. 2008. Sistem Manajemen HACCP (Hazard Analysis Critical Control Points). Bumi Aksara, Jakarta (ID).

Tjiptono F, Diana A. Total Quality Management. Andi Offset, Yogyakarta (ID).

Winarno FG, Surono. 2004. GMP: Cara Pengolahan Pangan yang Baik, cetakan ke 2. M-BRIO Press, Bogor (ID).

Wiryanti J, Witjaksono. 2001. Konsepsi HACCP. Jakarta (ID). 